\title{
Two-Dimensional Hillslope Scale Soil Erosion Model
}

\author{
Y. $A n^{1}$ and Q. Q. $\mathrm{Liu}^{2}$
}

\begin{abstract}
On a hillslope, overland flow first generates sheet erosion and then, with increasing flux, it causes rill erosion. Sheet erosion (interrill erosion) and rill erosion are commonly observed to coexist on hillslopes. Great differences exist between both the intensities and incidences of rill and interrill erosion. In this paper, a two-dimensional rill and interrill erosion model is developed to simulate the details of the soil erosion process on hillslopes. The hillslope is treated as a combination of a two-dimensional interrill area and a onedimensional rill. The rill process, the interrill process, and the joint occurrence of rill and interrill areas are modeled, respectively. Thus, the process of sheet flow replenishing rill flow with water and sediment can be simulated in detail, which may possibly render more truthful results for rill erosion. The model was verified with two sets of data and the results seem good. Using this model, the characteristics of soil erosion on hillslopes are investigated. Study results indicate that (1) the proposed model is capable of describing the complex process of interrill and rill erosion on hillslopes; (2) the spatial distribution of erosion is simulated on a simplified two-dimensional hillslope, which shows that the distribution of interrill erosion may contribute to rill development; and (3) the quantity of soil eroded increases rapidly with the slope gradient, then declines, and a critical slope gradient exists, which is about $15-20^{\circ}$ for the accumulated erosion amount.
\end{abstract}

DOI: 10.1061/(ASCE)HE.1943-5584.0000032

CE Database subject headings: Soil erosion; Slopes; Two-dimensional models.

\section{Introduction}

The hillslope is regarded as one of the basic units of a basin, while the practical hillslope is usually irregular. When the rainfall intensity exceeds soil infiltration, the excess rain flows down and first forms a sheet flow on a hillslope. In general, due to the irregularity of hillslopes, the sheet flow will concentrate into lower areas, which results in rill flows and the main route of overland runoff. Thus the hillslope can be conveniently divided into rill and interrill areas-the area between rills. Accordingly, soil erosion on hillslopes may be divided into interrill erosion generated by sheet flow and rill erosion generated by a concentrated flow in rills. The intensities and incidences of rill and interrill erosion are very different. When a rainstorm occurs, both of them are commonly observed coexisting on slopes, especially in the loess plateau area of China. Generally speaking, a minor watershed can be divided into a series of hillslopes and gullies. Taking it one step further, these hillslopes can be divided into smaller basic slopes that only include rill and interrill areas (Fig. 1). Owing to their different flow and erosion characteristics, both are commonly investigated.

An extensive investigation has been conducted in the past several decades on both rill and interrill erosion. The relationship between the interrill erosion rate and hydraulic conditions has

\footnotetext{
${ }^{1}$ Research Assistant, Institute of Mechanics, Chinese Academy of Sciences, Beijing 100190, China.

${ }^{2}$ Professor, Ph.D., Institute of Mechanics, Chinese Academy of Sciences, Beijing 100190, China (corresponding author). E-mail: qqliu@imech.ac.cn

Note. This manuscript was submitted on November 1, 2007; approved on September 26, 2008; published online on June 15, 2009. Discussion period open until December 1, 2009; separate discussions must be submitted for individual papers. This paper is part of the Journal of Hydrologic Engineering, Vol. 14, No. 7, July 1, 2009. CASCE, ISSN 10840699/2009/7-690-697/\$25.00.
}

been expressed in various kinds of forms empirically or semiempirically (Liebenow et al. 1990; Grosh and Jarrett 1994; Sharma et al. 1995; Bradford and Foster 1996; Zhang et al. 1998a; Gabet and Dunne 2003; Liu et al. 2005). Likewise, there has also been emphasis on the rill erosion rate (Moore and Burch 1986; Elliot and Laflen 1993; Tang and Chen 1997; Zhang et al. 1998b). A series of practical erosion models have also been developed such as water erosion predict project (WEPP) (Flanagan and Nearing 1995; Ascough et al. 1997). These models are not convenient in describing details of erosion processes (such as rill density at different segments), which are also important for understanding these complex processes.

Liu et al. (2006) proposed a simulation model for unified interrill and rill erosion on hillslopes. It is verified with some experiment data and shows good applicability. However, this model has its limitation. First, the model simplifies rill and interrill erosion into one dimension, which is similar to conventional models. Such a simplification gives few details of the rill erosion process on hillslopes. As a result, temporal and spatial varied conditions, for example, rill status, cannot be considered accurate. Second, an empirical conflux coefficient is used to model the influence of the joint occurrence of rill and interrill processes. The confluence relationship, i.e., water and sediment transports from interrill to rill, should vary with flow conditions. These problems not only obstruct the further application of the model but also would produce unnatural results under some conditions.

Actually, when rill erosion occurs on slopes, most of the sediment eroded by sheet flow only travels for a short distance, then converges into rills, and is mainly transported by rill flow. As hydraulic conditions of the rill and interrill areas are remarkably different, ignorance of the joint occurrence may induce significant error, especially when the rill condition varies temporally and spatially on the hillslope. Therefore, the objective of this research is to develop a process-oriented two-dimensional rill and interrill erosion model based on the model proposed by Liu et al. (2006). 


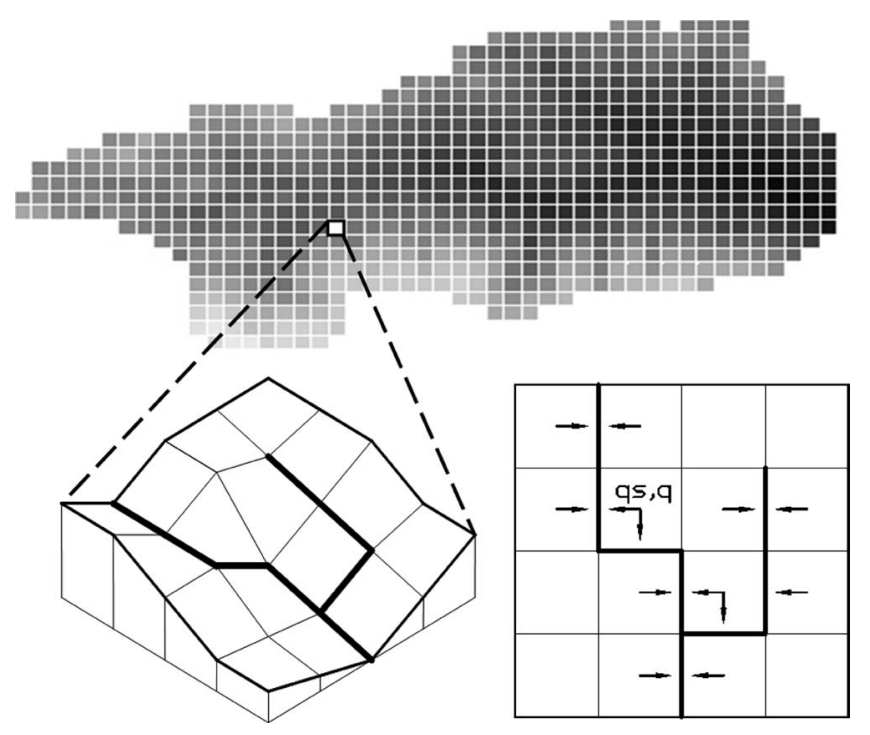

Fig. 1. Raster map of a watershed and the constitution of a representative slope element: (a) one basic hillslope of a small basin includes both rill and interrill areas; (b) top view: interrill areas replenish rill with water and sediment)

Erosion characteristics are also investigated on a representative hillslope using the proposed model. Thus the erosion characteristics on a hillslope, which may contain complex rills, can be simulated more reasonably, even if rill conditions vary acutely. And the parameter selection on the hillslope may confront less confusion accordingly.

\section{Model Description}

The proposed model in this paper consists of three modules: rill erosion, interrill erosion, and the joint occurrence of rill and interrill erosion. We assumed the following for simplification: (1) the rill is fully developed, i.e., longitude development of rills is neglected, and its hydrograph does not change acutely; (2) the landform evolution caused by erosion is not taken into account; (3) subsurface flow is not considered; and (4) the flow in rills comes from the concentration of sheet flow and the sediment laden by rill flow is derived from both rill erosion and inflow from lateral interrill areas.

\section{Interrill Erosion Process}

The interrill erosion process mainly entails the processes of infiltration, interrill flow, sheet erosion, and sediment transport.

\section{Soil Infiltration}

Soil infiltration is a precursory process for runoff formation. A revised Green-Ampt infiltration model was employed to describe the process of rainfall infiltration. Modifications by Mein and Larson (1973), Chu (1978), and Chen and Young (2006) are also introduced.

\section{Overland Flow and Sediment Transport in Interrill Area}

As an effective approximation of the St. Venant equations, the kinematic wave approximation has been applied successfully to overland flow on hillslopes. A two-dimensional kinematic wave model proposed by Liu et al. (2004) was employed to describe
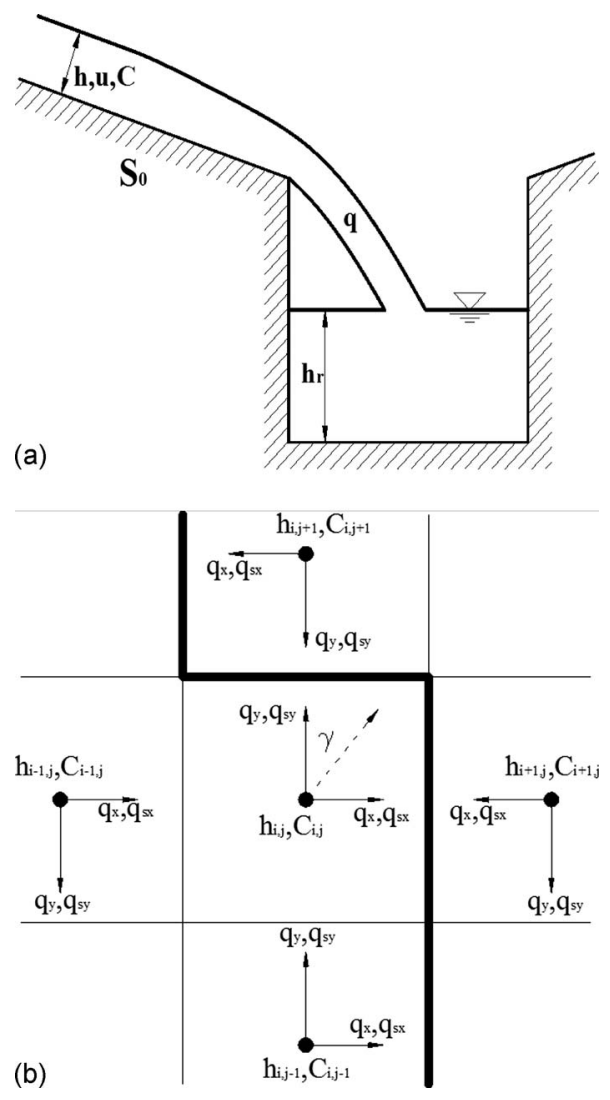

Fig. 2. Confluence process of flow and sediment: (a) single confluence process from interrill areas to rill; (b) a typical confluence routing on a complex hillslope

interrill overland flow. In this model, the discharge of overland flow on hillslopes is divided into the $x$ and $y$ directions [Fig. 2(b)]. These divided discharges are considered as the fluxes between one cell and its neighbor cells. The sediment continuity equation is introduced to depict sediment transport process. Thus the sheet flow equations are

$$
\begin{gathered}
\frac{\partial h}{\partial t}+\frac{\partial q_{x}}{\partial x}+\frac{\partial q_{y}}{\partial y}=p_{\mathrm{eff}} \\
q=\frac{1}{n_{i}} h^{5 / 3} S_{0}^{1 / 2}
\end{gathered}
$$

$$
q_{x}=q \cos \gamma
$$

$$
q_{y}=q \sin \gamma
$$

and the sediment continuity equation is

$$
\frac{\partial h C}{\partial t}+\frac{\partial q C}{\partial x}=D_{i}
$$

where $h(\mathrm{~m})=$ water depth; $q\left(\mathrm{~m}^{2} \mathrm{~s}^{-1}\right)=$ unit width discharge; $p_{\text {eff }}=$ effective rainfall intensity; $n_{i}\left(\mathrm{~s} \mathrm{~m}^{-1 / 3}\right)=$ Manning roughness coefficient; $S_{0}=$ slope gradient; $q_{x}$ and $q_{y}=$ unit width discharge components in the $x$ and $y$ directions, respectively, and $\gamma=$ angle of current; $C\left(\mathrm{~kg} \mathrm{~m}^{-3}\right)=$ sediment concentration; while $D_{i}\left(\mathrm{~kg} \mathrm{~s}^{-1} \mathrm{~m}^{-2}\right)=$ interrill erosion rate representing the process of sediment detachment. 


\section{Interrill Erosion}

Interrill flow not only detaches soil particles, but also transports soil particles. Based on the experiments a semiempirical formula for the interrill erosion rate was obtained by Liu et al. (2005)

$$
\frac{D_{i} d}{R_{c}}=1.8 \times 10^{-9}\left(\frac{h}{d}\right)^{1.5}\left(1.05-0.85 e^{-4 \sin \theta}\right)
$$

where $R_{c}\left(\mathrm{~kg} \mathrm{~s}^{-1} \mathrm{~m}^{-1}\right)=$ saturated sediment-transport capacity of interrill flow; $d(\mathrm{~m})=$ the diameter of soil particles; and $h(\mathrm{~m})$ =corresponding interrill water depth. The saturated sedimenttransport capacity of interrill flow $R_{c}$ can be calculated by using the commonly used Low's formula (1989).

\section{Rill Erosion Process}

The rill erosion process by rill flow mainly consists of the following processes: rill flow, rill erosion, and sediment transport.

\section{Rill Flow and Sediment Transport}

The kinematic wave equations and the sediment continuity equation are employed to describe the rill erosion process. The width of the rill must be considered and the source term must include water and sediment inflows from interrill area, thus we have

$$
\begin{gathered}
\frac{\partial(h B)}{\partial t}+\frac{\partial(q B)}{\partial x}=S_{w_{-} \text {lat }} \\
q=\frac{1}{n} h^{5 / 3} S_{0}^{1 / 2} \\
\frac{\partial(h B C)}{\partial t}+\frac{\partial(q B C)}{\partial x}=D_{r} W+S_{S_{-} \text {lat }}
\end{gathered}
$$

where $C\left(\mathrm{~kg} \mathrm{~m}^{-3}\right)=$ sediment concentration; $D_{r}\left(\mathrm{~kg} \mathrm{~s}^{-1} \mathrm{~m}^{-2}\right)=$ rill erosion rate; $W=$ catchment width of rill; $S_{w_{-} \text {lat }}\left(\mathrm{m}^{2} \mathrm{~s}^{-1}\right)$ and $S_{S_{-} \text {lat }}$ $\left(\mathrm{kg} \mathrm{s}^{-1} \mathrm{~m}^{-1}\right)=$ source terms that indicate water and sediment inflow rate from the interrill area to the rill; and $B=$ width of the rill flow that can be calculated using the following empirical expression (Liu et al. 2006):

$$
B=0.596 Q^{0.316} S_{0}^{-0.23}
$$

where $Q\left(\mathrm{~m}^{3} \mathrm{~s}^{-1}\right)$ is the discharge of the rill flow. Admittedly, this kind of empirical formula does have great limitations, but it is considered as acceptable in our model because experiments, from which similar formulas are generalized, cover the main range of the model's application.

\section{Rill Erosion}

A nonequilibrium sediment transport model for rill erosion (Liu et al. 2006) is employed. The rill erosion rate is assumed to be proportional to the difference between the maximum sediment transport capacity of rill flow, $T_{c}\left(\mathrm{~kg} \mathrm{~s}^{-1} \mathrm{~m}^{-1}\right)$ and the actual sediment transport rate $q_{s}\left(\mathrm{~kg} \mathrm{~s}^{-1} \mathrm{~m}^{-1}\right)$; one has

$$
D_{r}=\alpha\left(T_{c}-q_{s}\right)
$$

where $\alpha\left(\mathrm{m}^{-1}\right)=$ coefficient with a length of reciprocal dimension. The coefficient, $\alpha$, was obtained by Li et al. (2003) from experimental data

$$
\frac{1 / \alpha}{R}=1.5 \times 10^{4}\left[\frac{\tau-\tau_{c}}{\left(\rho_{s}-\rho\right) g d}\right]^{0.15}\left(\frac{u}{\sqrt{g d}}\right)^{-1} S_{0}^{1.5}
$$

where $R(\mathrm{~m})=$ hydraulic radius; $\tau(\mathrm{Pa})=$ flow shear stress; and $\tau_{c}$ $(\mathrm{Pa})=$ critical shear stress.

The sediment transport capability of the rill flow $T_{c}$ $\left(\mathrm{kg} \mathrm{s}^{-1} \mathrm{~m}^{-1}\right)$ can be calculated by the well-known Yalin's formula (Yalin 1963). Dou's formula (1999), which takes the influence of the slope and cohesive force into consideration, is chosen for representing the critical shear stress $\tau_{c}$.

\section{Confluence of Flow and Sediment from Interrill Area into Rills}

The confluence process of flow and sediment from interrill areas into rills is complex: it involves surface and subsurface flow, while only surface flow is discussed here. Two-dimensional grids are drawn on the interrill areas. According to real landform, onedimensional rill elements are placed at the corresponding borders of the related interrill grids. The flow in one interrill element, which is divided into two directions, pours into its neighboring rill or interrill elements [Fig. 2(b)]. The rill elements, correspondingly, take the interrill inflow as the source term on both hydrodynamics equations and sediment-transport equations.

Assuming rills are fully developed, the confluence process would not relate to the water depth of rills. Hence the calculation of discharge from the interrill to the rill can be simplified into the problem of flowing over a backward-facing step [Fig. 2(a)]. Although overland flow is very thin in general, water depth around the rill still can be large enough to take the jet effect into consideration. A basic formula of weir flow is employed to calculate discharges

$$
q_{\text {jet }}=m \sqrt{2 g}\left(h+\frac{u^{2}}{2 g}+L_{\text {side }} S_{0}\right)
$$

where $q_{\text {jet }}=$ unit discharge from the interrill to the rill; $h$ and $u$ = water depth and velocity at the upper reaches; $L_{\text {side }}=$ distance between the upper reach and the edge of rill; and $m=$ coefficient in hydraulics that can be determined by experimental data.

\section{Model Validation}

Two sets of different observation data were used to validate the proposed model in this paper. The first set of data, which was obtained from experiments conducted on a soil flume with artificial rainfall at the Northwest Institute of Water and Soil Conservation, Chinese Academy of Science, was used to verify the temporal variation of the accumulated erosion amount. The test plot was a $3.2 \mathrm{~m} \times 1.0 \mathrm{~m}$ soil flume and the experimental soil was the local loess with a median grain size of $d_{50}=0.02 \mathrm{~mm}$. The bulk density of soil $\rho_{s}$, the initial moisture content $\theta_{i}$, and the saturated volumetric water content $\theta_{s}$ are listed below: $\rho_{s}=1.33 \mathrm{~g} \mathrm{~cm}^{-3}, \theta_{i}=0.2206, \theta_{s}=0.5027$. The infiltration coefficient $K$ and soil suction $S$ of the loess soil used in the experiments are $1.67 \times 10^{-6} \mathrm{~m} \mathrm{~s}^{-1}$ and $0.15 \mathrm{~m}$, respectively.

Figs. 3(a and $b)$ show the simulated results of the runoff discharge and accumulated erosion amount by the model, respectively. In this case study, the rain intensity is $1.04 \mathrm{~mm} \mathrm{~min}^{-1}$ and the inclination angle of the slope is $25^{\circ}$; no observable rill recorded. On the whole, the model satisfactorily predicted both the runoff discharge and accumulated erosion amount. 

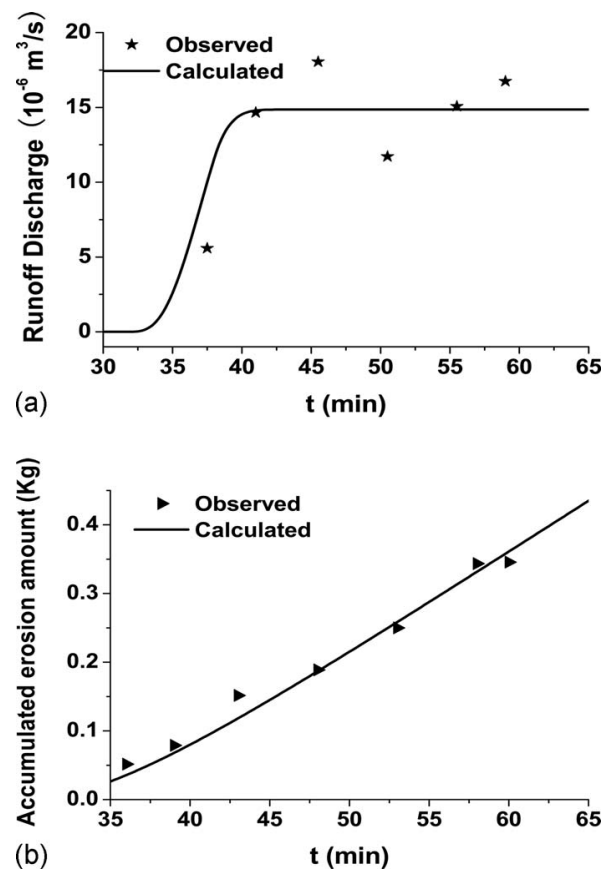

Fig. 3. Comparison of experimental and predicted results: (a) runoff discharge at outlet; (b) accumulated erosion amount (experimental parameters: rain intensity: $1.04 \mathrm{~mm} \mathrm{~min}^{-1}$; slope: $25^{\circ}$; no observable rill occurs)

The second set of data, obtained by Kong and Zhang (2003), was used to verify the spatial distribution of erosion. The test case is $10 \mathrm{~m}$ long and $2 \mathrm{~m}$ wide. The gradient is fixed to $15^{\circ}$. The test case was divided into four parts along the direction of the longer side. In this way, the distribution of the erosion amount was observed. The experimental soil was local loess in Yanglin, China. Its bulk density was $1.01 \mathrm{~g} \mathrm{~cm}^{-3}$ and its grain size $d_{50}$ was $0.04 \mathrm{~mm}$. Rainfall intensity varied from 0.72 to $2.4 \mathrm{~mm} \mathrm{~min}^{-1}$ and the precipitation amount was fixed to $38 \mathrm{~mm}$ in the experiments.

Kong and Zhang (2003) divide their experimental data into the "large rain intensity case" and the "small rain intensity case" using rain intensity of $2 \mathrm{~mm} \mathrm{~min}^{-1}$ as a split line. According to the experiment records, rill densities are assumed to be $2.0 \mathrm{~m}^{-1}$ and $0.6 \mathrm{~m}^{-1}$ in calculations, respectively. As shown in Fig. 4(a), the observed data and the calculated values of average runoff depths are in good agreement. Fig. 4(b) shows the distribution of unit erosion quantity along the slope, which indicates that erosion increases distinctly where the rill starts (as being recorded in experiment), and the result seems good.

\section{Characteristics of Soil Erosion on Slopes}

As a typical case and application, the erosion characteristics on a simplified slope, which only contains one rill as representative of the almost parallel rills, are discussed by a series of numerical experiments. Influences of the slope gradient to erosion characteristics are also investigated.

\section{Numerical Experiment Model}

Based on the assumption that every rill has its independent catchment area, the model slope (Fig. 5) contains one rill and
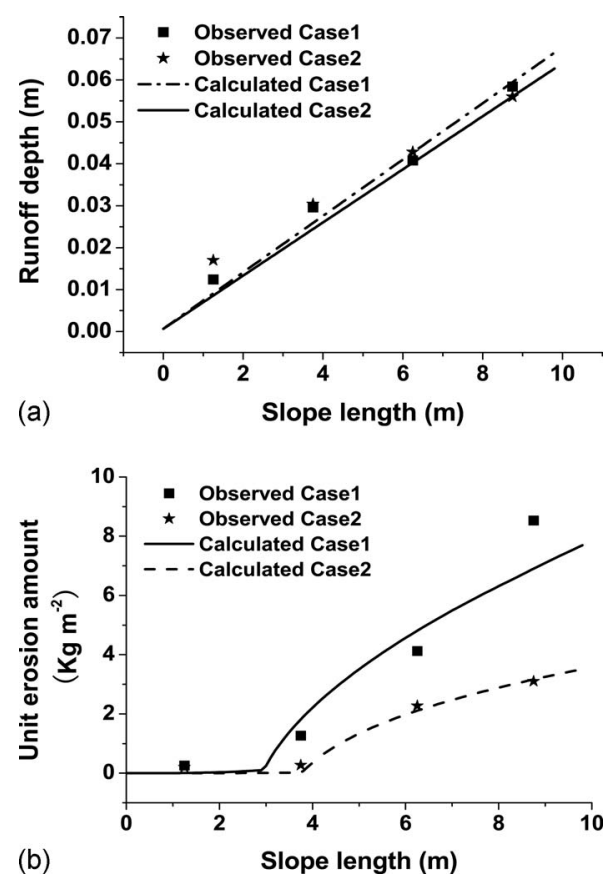

Fig. 4. Comparison of experimental and predicted results (Case 1, "large rain intensity"; Case 2, "small rain intensity"): (a) overall runoff depth distribution; (b) the distribution of unit erosion amount

its interrill catchment. The rill is in the middle of the slope and the topography of interrill area is generated using the following equation:

$$
z=(L-x) \sin \theta+\tan \theta_{\text {side }} \cdot\left|\frac{W}{2}-y\right|
$$

where $z=$ elevation; $L=$ slope length, which is $15 \mathrm{~m}$ in all studied cases; $W=$ catchment width of the rill; $\theta=$ slope gradient; and $\theta_{\text {side }}=$ interrill transverse slope gradient, which affects the confluence process of the interrill area to the rill.

Table 1 shows relative parameters in the numerical experiment. In the table, $n_{\mathrm{r}}$ is the Manning roughness coefficient of the

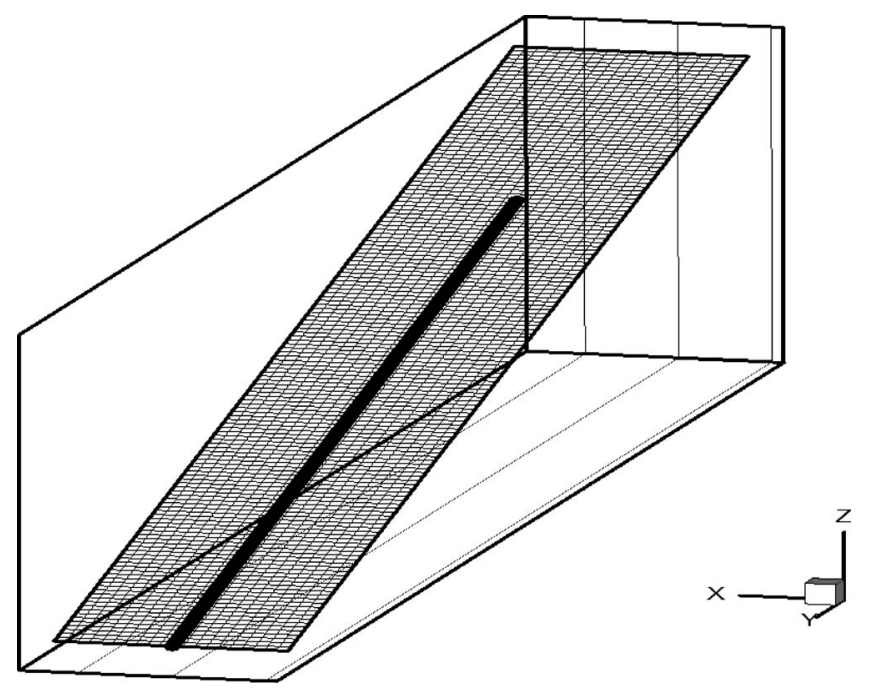

Fig. 5. Model slope used in numerical experiments (the black line represents rill while the other mesh represents interrill areas) 
Table 1. Parameters Used in the Numerical Experiment

\begin{tabular}{lcccccc}
\hline $\begin{array}{l}\theta_{s} \\
(\%)\end{array}$ & $\begin{array}{c}\theta_{i} \\
\%\end{array}$ & $\begin{array}{c}K \\
\left(\mathrm{~mm} \mathrm{~h}^{-1}\right)\end{array}$ & $\begin{array}{c}S \\
(\mathrm{~m})\end{array}$ & $\begin{array}{c}\gamma_{0 *} \\
\left(\mathrm{~N} \mathrm{~m}^{-3}\right)\end{array}$ & $\begin{array}{c}\gamma_{0} \\
\left(\mathrm{~N} \mathrm{~m}^{-3}\right)\end{array}$ & $\begin{array}{c}n_{r} \\
\left(\mathrm{~m}^{-1 / 3} \mathrm{~s}\right)\end{array}$ \\
\hline 57 & 12 & 0.75 & 0.06 & 1100 & 1300 & 0.035 \\
\hline
\end{tabular}

rill; $n_{i}$ is the roughness coefficient of the interrill area. Other symbols are the same as defined previously. A fixed amount of precipitation $(60 \mathrm{~mm})$ and rainfall intensities were used in the numerical model experiment.

\section{Result and Discussion}

\section{Typical Case Study}

In this case study, the slope inclination of the test case is $30^{\circ}$, the intensity of rainfall is $2.0 \mathrm{~mm} \mathrm{~min}^{-1}$, the length of the rill on the slope takes $66 \%$ of the slope length, and the catchment width of the rill flow is $0.5 \mathrm{~m}$.

Fig. 6 shows the simulated results of runoff and erosion for the reference case. The runoff discharge and sediment transport rate at the outlet response to rain rapidly [Figs. 6(a and b)]. The runoff discharge in the rill flow is remarkably greater than on the interrill area. It is distinct that the results conform to general knowledge of the erosion process on a hillslope. Because the rill is assumed to be fully developed, the unit accumulated erosion amount increases almost linearly with time [Fig. 6(c)]. The simulated result shown in Fig. 6(d) also shows the interesting fact that the depth of the rill flow increases fast near the head of the rill. This reflects that the rill provides a fast drain to the water on the upper interrill areas.

Distribution of the Rill and Interrill Erosion Intensity

The spatial distributions of the rill erosion intensity at different times are illustrated in Fig. 7(a). As is shown, the rill erosion intensity increases with slope length and the relation is sensitive to shifts of rain intensity. Mostly, the rill erosion intensity shows rapid growth at the beginning, while the incremental rate would reduce along with slope length sooner. This is the result of the nonlinearity of rill erosion, i.e., the erosion capacity of the flow decreases as sediment concentration grows.

The interrill erosion appears similar to the rill erosion on a temporal process, while they are very different on spatial distribution. The interrill erosion intensity around the head of the rill is largest along the slope [Fig. 7(b)]. This is because the rill provides a far more efficient access to draining the water than the interrill areas do. As a matter of fact, this distribution form of interrill erosion may have a positive effect on rill development. Because the intense interrill erosion around the rill head would induce changes in the topography, which lead to a more concentrated flow, this in turn would render further erosion around the rill head and contribute to the migration of the rill head.

\section{Distribution of Averaged Erosion Intensity}

Fig. 8 shows the spatial distributions of the interrill erosion rate, the rill erosion rate, and the total erosion rate on the hillslope. Distinctly, the averaged intensity of interrill erosion increases until reaching its peak value around the rill head and then decreases slightly, finally leading to stable erosion intensity. The rill erosion intensity rises along the slope although the increase rate decelerates in the lower reaches of the slope. Thus the total erosion intensity increases rapidly near the rill head and then reaches a steady growth rate. The simulated results also clearly show that
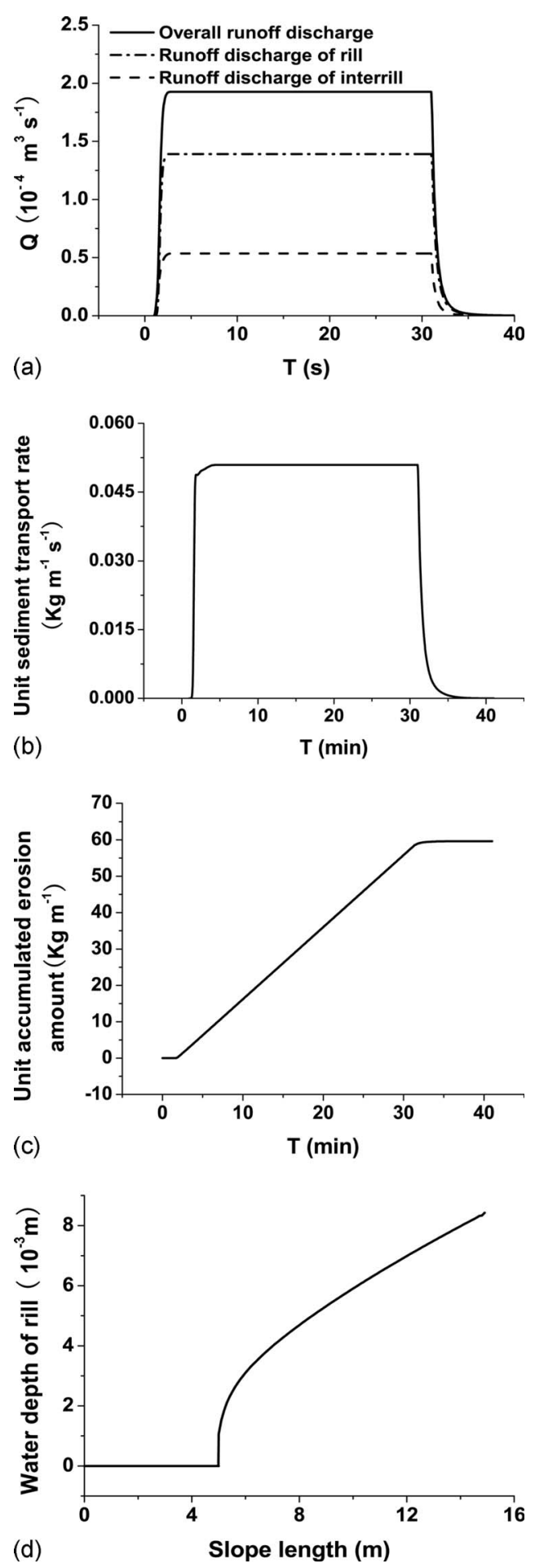

Fig. 6. Numerical results of the reference case: (a) runoff discharge at the outlet; (b) unit width sediment transport rate at the outlet; (c) unit width accumulated erosion amount; and (d) distribution of water depth of rill flow, $T=20 \mathrm{~min}$ 

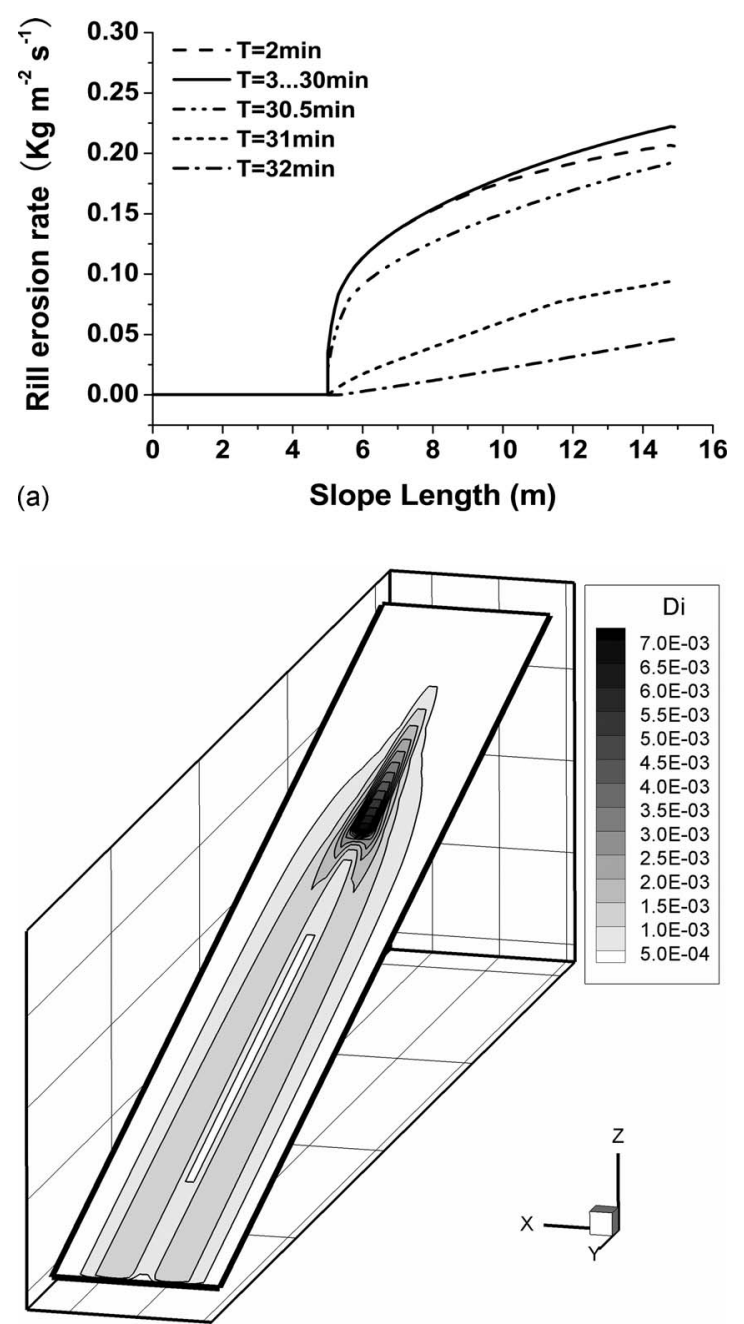

(b)

Fig. 7. Erosion intensity distribution on the test slope: (a) rill erosion intensity distribution, rain stops at $30 \mathrm{~min}$; (b) interrill erosion intensity distribution on the test slope, $T=20 \mathrm{~min}$

the incidence and intensity of rill and interrill erosion are highly different. Although the incidence of interrill erosion is, further, more than the incidence of rill erosion, the intensity of rill erosion is much larger than the intensity of interrill erosion, i.e., the rill erosion is the dominant manner of erosion on hillslopes.

\section{Influence of Slope Gradient}

Taking the same test case, the influences of the slope gradient on soil erosion is studied numerically. In this case study, rain intensity is $2.0 \mathrm{~mm} \mathrm{~min}^{-1}$, rill length is $2 / 3$ of the slope length, and catchment width is $0.5 \mathrm{~m}$. The simulated results [Fig. 9(a)] show that the distributions of the averaged unit erosion amount for different slope gradients are quite dissimilar with each other, which indicates the slope gradient is a significant effect factor for soil erosion on hillslopes. The influence of the slope gradient on soil erosion was rather complex. For steady erosion, the calculation results show that the unit erosion amount initially increased with the slope gradient and then began to decrease when the slope gradient reached a critical value. It is obvious that there exists a critical slope gradient, which would render the largest erosion amount. In this study, the critical slope gradient is about $15-20^{\circ}$

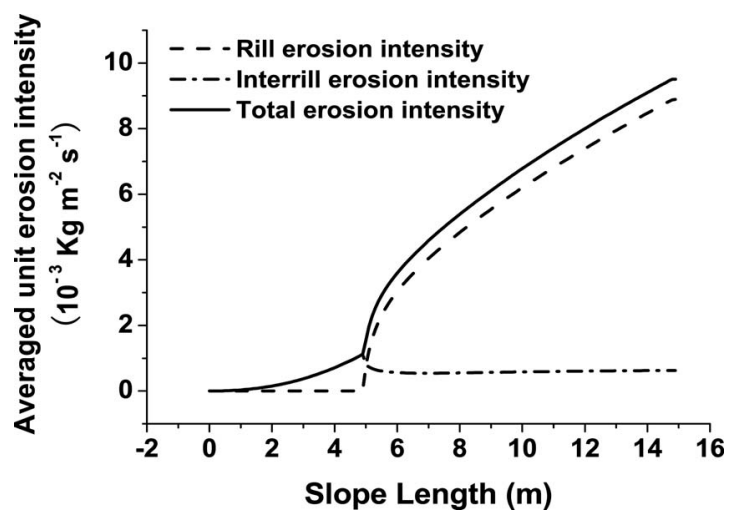

Fig. 8. Spatial distribution of averaged unit erosion intensity on slope, $T=20 \mathrm{~min}$

[Fig. 9(b)] and the angle varies with parameters or slope conditions. Similar values have been reported in many experiments (Chen 1985; Hu and Jin 1999). The critical angle of erosion is a compound result of several factors. Total runoff, i.e., precipitation subtracting infiltration loss, may be one of the important factors.

\section{Concluding Remarks}

A two-dimensional rill and interrill erosion model is proposed to achieve a more detailed description of the erosion process on hillslopes. The joint occurrence of rill and interrill erosion is modeled and the calculation of interrill and rill erosion are linked together. In this way, the erosion process on complex hillslopes
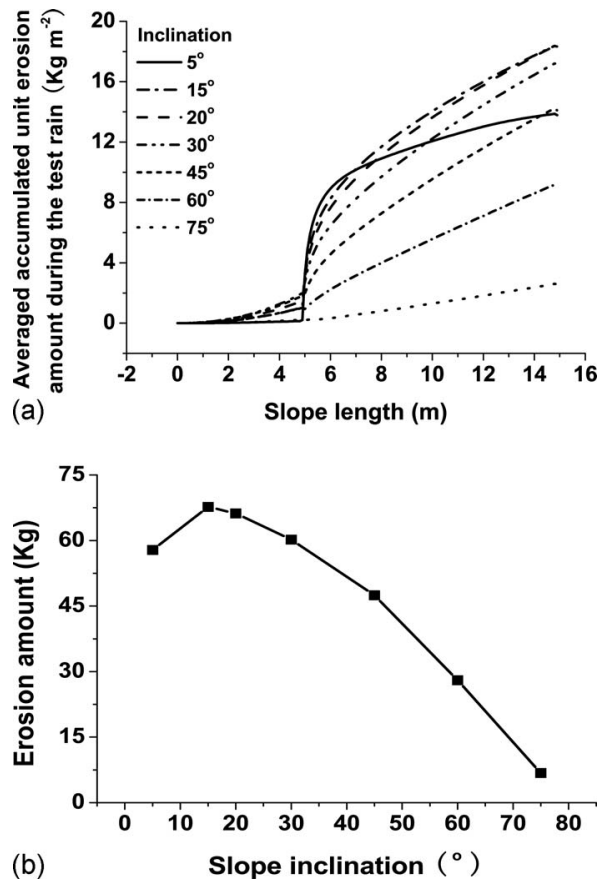

Fig. 9. Influence of slope gradient on soil erosion: (a) distributions of unit erosion amount under different slope gradient; (b) influence of slope gradient to erosion amount 
can be properly modeled and simulated. The validity of the model is verified using two sets of experiments. Thereafter, the model is employed to discuss the distribution characteristics of soil erosion. The influence of the slope gradient is also studied through numerical experiments. The following basic conclusions are drawn from this study:

1. The proposed model does render details of the erosion process that help us to understand the mechanism of soil erosion more, and the result seems reasonable.

2. The distribution characteristics of rill and interrill erosion are very different. Within the range of this investigation, rill erosion intensity increases rapidly, while the increase rate slows down gradually; interrill erosion shows fewer changes along the slope compared with rill erosion. An interesting phenomenon is that interrill erosion intensity would be larger around the rill head than other areas, which probably contributes to rill development.

3. The slope gradient has a great impact on erosion distribution. With the increase of the slope gradient the erosion amount increases initially and then decreases. The critical angle is about $15-20^{\circ}$ (different with specific parameters) in our numerical experiments, which is consistent with a lot of field and laboratory tests.

\section{Acknowledgments}

This research was financially supported by the National Natural Science Foundation of China (NSFC) (Grant No. 10825211.

\section{Notation}

The following symbols are used in this paper:

$B=$ rill width $(\mathrm{m})$;

$C=$ sediment concentration $\left(\mathrm{kg} \mathrm{m}^{-3}\right)$;

$D_{i}=$ interrill erosion rate $\left(\mathrm{kg} \mathrm{m}^{-2} \mathrm{~s}^{-1}\right)$;

$D_{r}=$ rill erosion rate $\left(\mathrm{kg} \mathrm{m}^{-2} \mathrm{~s}^{-1}\right)$;

$d=$ diameter of sediment $(\mathrm{m})$;

$d_{50}=$ median grain size of sediment $(\mathrm{m})$;

$g=$ acceleration due to gravity $\left(\mathrm{m} \mathrm{s}^{-2}\right)$;

$h=$ water depth (m);

$i=$ infiltration rate $\left(\mathrm{m} \mathrm{s}^{-1}\right)$;

$K=$ saturate conductivity of soil (or infiltration coefficient) $\left(\mathrm{m} \mathrm{s}^{-1}\right)$;

$L=$ length of slope $(\mathrm{m})$;

$n=$ Manning roughness coefficient $\left(\mathrm{s} \mathrm{m}^{-1 / 3}\right)$;

$p=$ rainfall intensity $\left(\mathrm{m} \mathrm{s}^{-1}\right)$;

$Q=$ rill runoff discharge $\left(\mathrm{m}^{3} \mathrm{~s}^{-1}\right)$;

$q=$ unit discharge of overland flow $\left(\mathrm{m}^{2} \mathrm{~s}^{-1}\right)$;

$q_{s}=$ sediment transport rate per unit width $\left(\mathrm{kg} \mathrm{m}^{-1} \mathrm{~s}^{-1}\right)$;

$R=$ hydraulic radius $(\mathrm{m})$;

$R_{c}=$ unit transport capacity of interrill flow $\left(\mathrm{kg} \mathrm{m}^{-1} \mathrm{~s}^{-1}\right)$;

$S=$ soil suction $(\mathrm{m})$

$S_{0}=$ slope gradient $S_{0}=\sin \theta$;

$S_{f}=$ energy slope;

$S_{w_{-} \text {lat }}=$ lateral water income from interrill to rill $\left(\mathrm{m}^{2} \mathrm{~s}^{-1}\right)$;

$S_{S_{-} \text {lat }}=$ lateral sediment income from interrill to rill $\left(\mathrm{kg} \mathrm{m}^{-2} \mathrm{~s}^{-1}\right)$;

$T_{c}=$ unit transport capacity of rill flow $\left(\mathrm{kg} \mathrm{m}^{-1} \mathrm{~s}^{-1}\right)$;

$u=$ mean velocity of flow $\left(\mathrm{m} \mathrm{s}^{-1}\right)$;

$W=$ width of slope $(\mathrm{m})$;

$x=$ coordinate along the slope $(\mathrm{m})$;

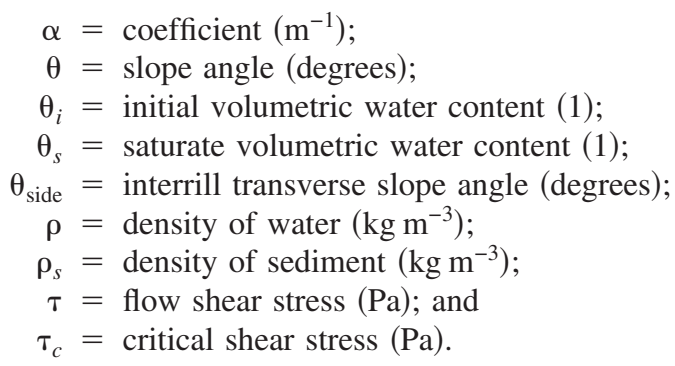

\section{References}

Ascough, J. C., Baffaut, C., Nearing, M. A., and Liu, B. Y. (1997). "The WEPP watershed model. I: Hydrology and erosion." Trans. ASAE, 40(4), 921-933.

Bradford, J. M., and Foster, G. R. (1996). "Interrill soil erosion and slope steepness factors." Soil Sci. Soc. Am. J., 60(3), 909-915.

Chen, F. Y. (1985). "Experiment on influence of slope gradient to soil erosion." Soil Water Conservation in China, 1985(2), 24-30 (in Chinese).

Chen, L., and Young, M. H. (2006). "Green-Ampt infiltration model for sloping surfaces." Water Resour. Res., 42, W07420.

Chu, S. T. (1978). "Infiltration during an unsteady rain." Water Resour. Res., 14(3), 461-466.

Dou, G. R. (1999). "Incipient motion of coarse and fine sediment." J. Sediment Res., 6, 1-9 (in Chinese).

Elliot, W. J., and Laflen, J. M. (1993). "A process-based rill erosion model." Trans. ASAE, 36(1), 65-72.

Flanagan, D. C., and Nearing, M. A. (1995). "USDA-Water erosion prediction project: Hillslope profile and watershed model documentation." Technical Rep. prepared for USDA, National Soil Erosion Research Laboratory, West Lafayette, Ind.

Gabet, E. J., and Dunne, T. (2003). "Sediment detachment by rain power." Water Resour. Res., 39(1), 1002.

Grosh, J. L., and Jarrett, A. R. (1994). "Interrill erosion and runoff on very steep slopes." Trans. ASAE, 37(4), 1127-1133.

Hu, S. X., and Jin, C. X. (1999). "Theoretical analysis and experimental study on the critical slope of erosion." Acta Geogr. Sin., 54(4), 347 356 (in Chinese).

Kong, Y. P., and Zhang, K. L. (2003). "The distribution of soil loss on the surface of loess slope." J. Sediment Res., 2003(1), 33-38 (in Chinese).

Li, J. C., Liu, Q. Q., and Zhou, J. F. (2003). "Environmental mechanics in China." Adv. Appl. Mech., 39, 217-306.

Liebenow, A. M., Elliot, W. J., Laflen, J. M., and Kohl, K. D. (1990). "Interrill erodibility-Collection and analysis of data from cropland soils." Trans. ASAE, 33(6), 1882-1888.

Liu, Q. Q., Chen, L., Li, J. C., and Singh, V. P. (2004). "Two-dimensional kinematic wave model of overland flow." J. Hydrol., 291(1-2), 2841.

Liu, Q. Q., Singh, V. P., and Xiang, H. (2005). "Plot erosion model using gray relational analysis method." J. Hydrol. Eng., 10(4), 288-294.

Liu, Q. Q., Xiang, H., and Singh, V. P. (2006). "A simulation model for unified interrill erosion and rill erosion on hillslopes." Hydrolog. Process., 20(3), 469-486.

Low, H. S. (1989). "Effect of sediment density on bed-load transport." J. Hydraul. Eng., 115, 124-138.

Mein, R. G., and Larson, C. L. (1973). "Modeling infiltration during a steady rain." Water Resour. Res., 9(2), 384-394.

Moore, I. D., and Burch, G. J. (1986). "Sediment transport capacity of sheet and rill flow: Application of unit stream power theory." Water Resour. Res., 22, 1350-1360.

Sharma, P. P., Gupta, S. C., and Foster, G. R. (1995). "Raindrop-induced soil detachment and sediment transport from interrill areas." Soil Sci. Soc. Am. J., 59(3), 727-734.

Tang, L. Q., and Chen, G. X. (1997). “The dynamic model of runoff and 
sediment generation in small watershed." J. Hydrodynam., 12(2), 164-174 (in Chinese).

Yalin, M. S. (1963). "An expression for bed-load transportation.” J. Hydr. Div., 89, 221-248.

Zhang, K. L., Akiyoshi, Y., and Zhang, X. Q. (1998a). “A laboratory study on rill erosion and sediment delivery on the slope." Geogr. Res., 17(2), 163-170 (in Chinese).

Zhang, X. C., Nearing, M. A., Miller, W. P., Norton, L. D., and West, L. T. (1998b). "Modelling interrill sediment delivery." Soil Sci. Soc. Am. J., 62(2), 438-444. 